\title{
Lise de Mycoplasma mycoides subesp. mycoides tipo LC por diferentes métodos
}

\author{
Lysis of Mycoplasma mycoides subsp. mycoides LC type \\ by different methods
}

\author{
Valquíria Pinto Barbosa, ${ }^{*}$ Maria das Graças Miranda Danelli, ${ }^{*}$ Jackeline de Oliveira Pontes Lizeu, \\ Elmiro Rosendo do Nascimento**
}

\begin{abstract}
Resumo
O objetivo deste trabalho foi avaliar diferentes métodos de lise celular para obtenção da membrana plasmática de Mycoplasma mycoides subesp. mycoides tipo LC. Foram analisados os métodos de Lise Osmótica Regular (LR), Lise Osmótica Regular com pré-incubação em Glicerol (LG), Lise com Digitonina (LD), Lise Alcalina (LA) e Lise por Congelamento e Descongelamento (LCD). Todas as técnicas avaliadas foram eficientes em lisar mais de $70 \%$ das células desse micoplasma, com exceção da LCD (52\%). O método de LA apresentou o melhor resultado, com $84 \%$ de lise celular no momento da realização do choque osmótico, apresentando lise máxima (89\%) após 20 minutos de incubação da cultura a $37^{\circ} \mathrm{C}$.
\end{abstract}

Palavras-chave: Lise osmótica; Mycoplasma mycoides subesp; mycoides Tipo LC.

\begin{abstract}
The objective of this work was to evaluate different methods of cellular lysis to obtain Mycoplama mycoides subesp. mycoides LC Type plasmatic membrane. The methods analyzed were: Regular Osmotic Lysis (LR), Osmotic Lysis after Preloading Cells with Glycerol (LG), Digitonin-Induced Lysis (LD), Alkali Lysis (LA) and Alternate Freezing and Thawing Lysis (LCD). All of them were efficient to desrupt, more than $70 \%$ of mycoplasma cells, except LCD method (52\%). The LA method showed the best results, with $87 \%$ of cellular lysis at the moment of osmotic shock, and showed maximum of lysis (89\%) after 20 minutes of culture incubation at $37^{\circ} \mathrm{C}$.
\end{abstract}

Keywords: Osmotic Lysis; Mycoplama mycoides subsp; mycoides LC Type.

\section{Introdução}

Os micoplasmas são os menores e mais simples procariontes, que diferem das bactérias convencionais por não apresentarem parede celular nem estruturas celulares membranosas (Razin, 1979). Essas características próprias dos micoplasmas facilitam o isolamento e o estudo da sua membrana plasmática, eliminando os tediosos processos usualmente envolvidos na separação da parede celular e de outras estruturas membranosas das demais bactérias (Razin, 1983).

Devido à ausência desta parede, estes organismos são considerados frágeis, podendo ser rompidos pelos métodos tradicionais de lise. Com alguns micoplasmas é possível o uso de técnicas brandas de lise osmótica, pois tais organismos apresentam tendência a se romperem, mesmo durante o cultivo e por processos de lavagem e centrifugação (Rottew, 1983). Entretanto, outros micoplasmas necessitam de processos mais drásticos para serem rompidos (Grimellec et al., 1982) Alguns métodos têm sido utilizados para separar a membrana citoplasmática do micoplasma do conteúdo restante de sua célula, tais como: Lise Osmótica Regular (Razin, 1964 ; Nicolet et al., 1980), lise osmótica regular com pré-incubação em glicerol (Archer, Rodwell, 1982), Lise Alcalina (Villegas et al., 1975; Talkington et al., 1984), Lise com Digitonina (Razin, 1983 ; Nicolet et al., 1980), Lise por Congelamento e Descongelamento (Grimellec et al., 1982) e Lise por Sonicação (Levisohn et al., 1991 ; Sheldrake, Romalis, 1992). Entretanto, todos esses métodos apresentam vantagens e desvantagens no isolamento da membrana, para manter no máximo a integridade e pureza do material obtido.

O presente trabalho teve como objetivo comparar diferentes métodos de rompimento celular, para a obtenção de membrana plasmática do Mycoplasma mycoides subesp. mycoides tipo LC.

\footnotetext{
* Instituto de Veterinária/Universidade Federal Rural do Rio de Janeiro (UFRRJ). Endereço para correspondência: A/C Maria das Graças Miranda Danelli, Departamento de Microbiologia e Imunologia, Instituto de Veterinária, Universidade Federal Rural do Rio de Janeiro. Antiga Rodovia RioSão Paulo, Km 47 - Seropédica, RJ - CEP: 23890-000 - e-mail: danelli@ufrrj.br

${ }^{\star *}$ Faculdade de Veterinária/Universidade Federal Fluminense (UFF).
} 


\section{Material e métodos}

Organismo: O Mycoplasma mycoides subesp. mycoides tipo LC (cepa Y-Goat), foi cedido pelo Dr. Elmiro Rosendo do Nascimento, do Laboratório de Referência Nacional em Micoplasmologia, DESP/PSAVEMBRAPA- UFRRJ. Este organismo foi mantido em glicerol $(\mathrm{V} / \mathrm{V}) \mathrm{a}-20^{\circ} \mathrm{C}$, até o momento de uso.

Cultivo do organismo: O cultivo foi feito em meio de Hayflick modificado (Freundt, 1983), contendo $10 \%$ de soro eqüino inativado. As células foram obtidas na fase logarítmica de crescimento e em seguida centrifugadas a $12.000 \mathrm{xg}$ por 20 minutos a $4^{\circ} \mathrm{C}$, sendo lavadas uma vez em solução salina $0.25 \mathrm{M}, \mathrm{pH} 7,2-7,5$ e estocadas nesta mesma solução. As células utilizadas na Lise Osmótica com pré-incubação em glicerol foram lavadas em Tris- $\mathrm{HCl} 0,02 \mathrm{M}, \mathrm{pH} \mathrm{7,0}$ e estocadas nesta solução.

Determinação da fase logarítmica de crescimento: Cem microlitros de uma cultura estoque deste micoplasma foram inoculados em 1,0 mL de meio de Hayflick modificado. Após a sua ativação (aproximadamente 18 horas de incubação), foram feitos cultivos sucessivos, mantendo-se uma relação (amostra/meio) constante de $10 \%$, até o volume final de 100 $\mathrm{mL}$ de meio. A análise do crescimento da amostra foi feita através da leitura de sua densidade ótica (D.O.) por espectrofotometria a $660 \mathrm{~nm}$, em um intervalo de tempo de 24 horas.

\section{Métodos de Lise}

Lise Osmótica Regular (LR): A Lise Osmótica Regular foi realizada conforme descrito por Razin, 1964... Inicialmente foi determinada a D.O. a 500nm da suspensão celular em $1,0 \mathrm{~mL}$ de solução salina $0.25 \mathrm{M}, \mathrm{pH} 7,2-7,4$. O volume da suspensão celular que proporcionou uma D.O. em torno de 0.3-0.6 foi adicionado a quatro tubos, contendo $1,0 \mathrm{~mL}$ de água ultra pura (Milli-Q). Os tubos contendo as suspensões foram incubados em banho-maria a $37^{\circ} \mathrm{C}$, sendo retirados cada um nos intervalos de tempo de 0, 20, 40 e 60 minutos, para ser lida a mudança na D.O. da suspensão a 500nm. Imediatamente após a leitura da D.O., as suspensões foram centrifugadas a $7.000 \mathrm{xg}$ por $10 \mathrm{~min}$. e a D.O. do sobrenadante lida a $260 \mathrm{~nm}$, no sentido de se avaliar o rompimento celular mediante a liberação de ácido nucléico. $\mathrm{O}$ controle da lise foi feito, incubando a amostra em solução salina $0.25 \mathrm{M}$ à temperatura ambiente.

Lise Osmótica Regular com pré-incubação em glicerol (LG): Para a Lise osmótica com pré-incubação em glicerol, utilizouse uma suspensão celular previamente lavada em Tris- $\mathrm{HCl}$ $0.02 \mathrm{M}$. A mesma foi misturada a uma solução de glicerol $2 \mathrm{M}$ em banho-maria a $37^{\circ} \mathrm{C}$ por 30 minutos (Razin, 1983). Em seguida, às células pré-incubadas em glicerol, foi adicionada água ultrapura, seguindo a técnica já mençionada para LR.

Lise em Solução Alcalina (LA): A lise alcalina foi observada, incubando a suspensão celular em uma solução de tampão carbonato bicarbonato 0.05M, pH 10 (Davison et al., 1994), no mesmo tempo e temperatura da Lise Osmótica.

Lise com Digitonina (LD): A lise com digitonina foi feita segundo a técnica descrita por Razin, 1983. As células micoplásmicas foram misturadas a uma solução salina $0.25 \mathrm{M}$, contendo $25 \mathrm{mg}$ de digitonina/ml e incubadas a $37^{\circ} \mathrm{C}$ pelos mesmo tempo e temperatura da Lise Osmótica Regular.
Lise por Congelamento e Descongelamento alternado (LCD): A suspensão celular foi adicionada a um tubo teste, contendo água ultrapura e a outro contendo solução salina $0.25 \mathrm{M}$. Os tubos foram congelados em gelo seco/etanol e rapidamente transferidos para banho-maria a $40^{\circ} \mathrm{C}$ (Razin, Argaman, 1963). Este processo foi repetido seis vezes e a D.O. foi lida a $500 \mathrm{~nm}$, após cada processo.

\section{Resultados}

\section{Determinação da fase logarítmica de crescimento}

Conforme pode-se observar na Figura 1, a amostra de Mycoplasma mycoides subesp. mycoides tipo LC, crescida em meio de Hayflick modificado, entrou em sua fase logarítmica de crescimento após 5 horas de cultivo, mantendo-se nesta fase até o período de 11 horas de incubação. A partir deste período, o cultivo entrou na fase estacionária de crescimento, mantendo sua D.O. constante. A avaliação da sensibilidade à Lise Osmótica do Mycoplasma mycoides subesp. mycoides LC foi então realizada, coletando-se as células do cultivo em torno de 8 a 11 horas de incubação a $37^{\circ} \mathrm{C}$.

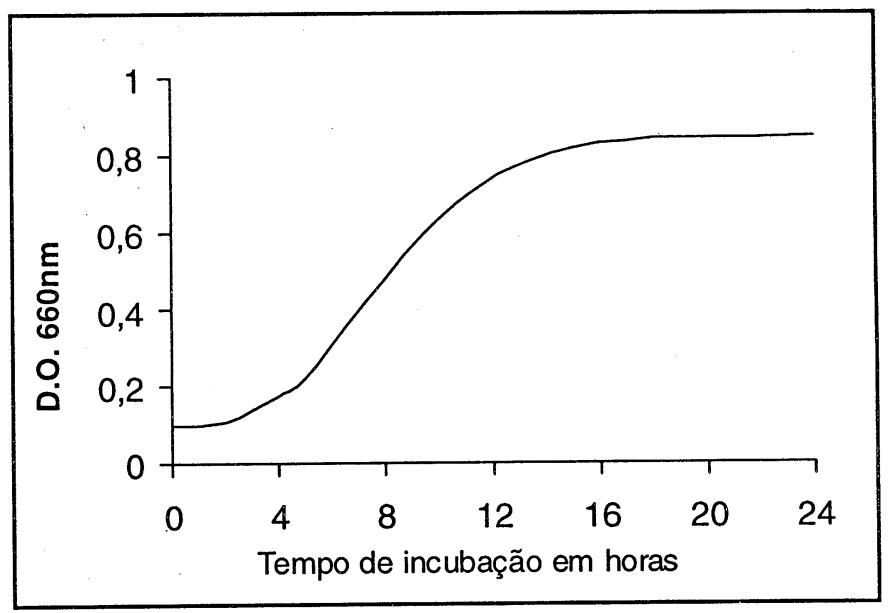

Figura 1: Curva de crescimento do Mycoplasma mycoides subesp. mycoides Tipo LC, em meio de Hayflick modificado, contendo soro eqüino $10 \%$.

\section{Lise Osmótica}

Os resultados alcançados nos diferentes métodos de lise, com exceção da LCD, estão demonstrados na Figura 2. Todas as técnicas avaliadas foram capaz de lisar em mais de $70 \%$ as células do $M$. mycoides subesp. mycoides tipo LC, no momento em que era adicionada a água ultrapura (tempo zero), havendo um pequeno acréscimo na percentagem de lise nos tempos subseqüentes. Os métodos de LR e LD apresentaram percentagem de lise semelhantes, sendo o máximo de lise $(78 \%)$ alcançado aos 20 minutos de incubação a $37^{\circ} \mathrm{C}$. A LG também apresentou uma percentagem de lise semelhante às duas anteriores, todavia, o máximo de lise $(82 \%)$ foi obtido aos 40 minutos de incubação. Nessa técnica, pôde-se observar que, durante a pré-incubação das células em glicerol, houve lise em $65 \%$ da suspensão celular, aumentando em mais $17 \%$ de lise após 40 minutos de incubação das células em água Milli-Q a $37^{\circ} \mathrm{C}$. A LA proporcionou 


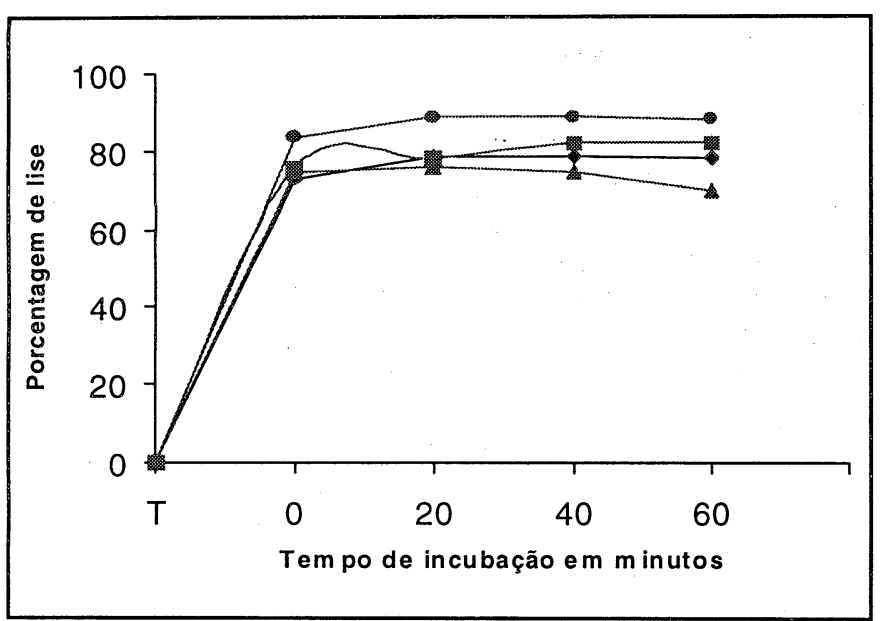

Figura 2: Lise osmótica de Mycoplasma mycoides subesp. mycoides Tipo LC - LR: Lise Osmótica Regular; LG: "Lise Osmótica com pré-incubação em Glicerol;

- LD: Lise com Digitonina; •LA: Lise Alcalina

$\mathrm{T}$ : Testemunho em solução salina $0.25 \mathrm{M}$ incubando à temperatura ambiente

uma maior percentagem de lise ( $84 \%$ ), já no tempo 0, apresentando um máximo de lise (89\%) em 20 minutos de incubação a $37^{\circ} \mathrm{C}$.

Os resultados de lise celular acima foram confirmados medindo-se a presença de ácido nucléico no sobrenadante das suspensões celulares a $260 \mathrm{~nm}$. Como era esperado, a liberação de ácido nucléico foi inversamente proporcional ao rompimento das células micoplásmicas, observada a $500 \mathrm{~nm}$ (resultados não apresentados).

A lise do micoplasma por congelamento e descongelamento em água não foi possível de ser avaliada, pois, à medida que células se rompiam, havia a formação de partículas agregadas em suspensão, impossibilitando a leitura da D.O. Entretanto, foi possível avaliar a lise, quando a suspensão celular foi feita em solução salina $0.25 \mathrm{M}$ (Figura 3). O máximo da lise celular foi observada no terceiro processo de congelamento e descongelamento, onde pôde-se observar um total de $52 \%$ de lise.

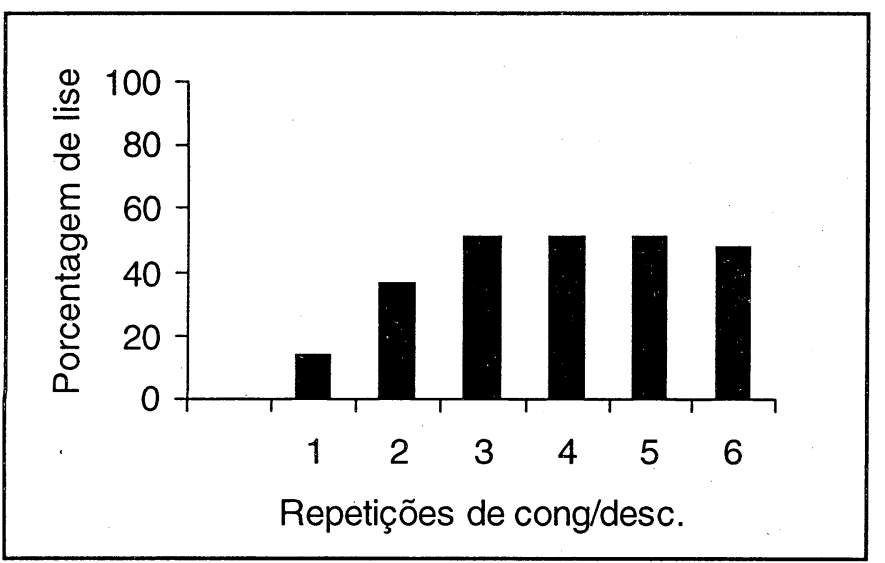

Figura 3: Lise de Mycoplasma mycoides subesp. mycoides Tipo LC por congelamento e descongelamento alternado.

\section{Discussão e conclusão}

Em função dos micoplasmas não possuírem parede celular, eles se tornam sensíveis a choque osmótico, ao mais simples e mais suave método de isolamento de membranas celulares. Entretanto, para que se obtenha um bom percentual de lise, é preciso que as células sejam colhidas na fase logarítmica de crescimento, visto que a sensibilidade dos organismos diminui bastante com a idade da cultura. A presençà de cátions divalentes em suspensão no meio, pode também providenciar uma completa proteção contra a Lise Osmótica (Cassel, Brown, 1983). Este fato foi observado no início deste estudo, onde obteve-se uma percentagem de Lise mais baixa $(58 \%)$, quando as células utilizadas foram colhidas na fase estacionária de crescimento, após 20 horas de incubação (resultados não demonstrados). No entanto, utilizando a suspensão celular colhida na fase logarítmica de crescimento $(8-11 \mathrm{~h})$, obteve-se um total de $79 \%$ de Lise Osmótica, após 40 minutos de incubação. Estes resultados estão em conformidade com os de Razin, 1964, que observou a sensibilidade do Mycoplasma mycoides subesp. capri ao choque osmótico.

Algumas espécies de micoplasmas apresentam-se menos sensíveis à Lise Osmótica quando tratadas pelos métodos tradicionais, a exemplo da espécie Mycoplasma gallisepticum. O uso do glicerol para auxiliar o rompimento destas células tem proporcionado bons resultados (Razin, 1983), pois o glicerol penetra livremente através da membrana celular dos micoplasmas, intensificando o choque osmótico pelo aumento da pressão interna das células. O micoplasma em estudo mostrou-se altamente sensível a $L G$, pois o mesmo sofreu lise no próprio glicerol, após 30 minutos de incubação.

Outros métodos de rompimento celular vêm sendo empregados, a exemplo da LD, LA e LCD. A Lise por Digitonina tem sido utilizada, por alguns autores, para a obtenção de membranas de certos micoplasmas, tais como Mycoplasma laidlawii e Mycoplasma mycoide subesp. capri (Razin, Argaman, 1963), Mycoplasma hyopneumoniae, Mycoplasma hyorhinis e Mycoplasma pneumoniae (Nicolet et al., 1980). A digitonina forma um complexo com o colesterol presente na membrana dos organismos pertencentes ao gênero Mycoplasma, causando um desarranjo na bicamada lipídica, aumentando a permeabilidade e posterior lise celular (Rottem, Razin, 1972). Uma das vantagens da lise feita por digitonina é a sua independência da idade da cultura, obtendo-se, portanto, bons resultados com micoplasmas que apresentam grandes dificuldades de crescimento. O micoplasma em estudo foi altamente sensivel à lise com digitonina, obtendo um máximo de lise de $76 \%$ de suas células após 20 minutos de incubação.

A lise alcalina tem sido utilizada para o rompimento de micoplasmas que são mais resistentes a choques osmóticos, tais como Mycoplasma gallisepticum e Thermoplasma acidophilum (Razin, 1979; Davidson et al., 1994). Porém, esta técnica pode alterar algumas proteínas de membrana ou a própria membrana pode ser solubilizada com valores de $\mathrm{pH}$ mais alto do que 10. O trabalho de Razin, Argman, 1963, demonstrou a sensibilidade das seguintes espécies: Mycoplasma laidlawwi, Mycoplasma hominis e Mycoplasma mycoides subesp. capri, à lise alcalina. No presente estudo, o Mycoplasma mycoides subesp. mycoides tipo LC mostrou- 
se altamente sensível à Lise Alcalina, obtendo um total de lise de $89 \%$ após 20 minutos de incubação. Este método foi considerado o mais drástico e o que proporcionou o maior rompimento celular.

Empregando-se a Lise por Congelamento e Descongelamento alternado, obtiveram-se resultados abaixo dos outros métodos de lise, com rompimento total de $52 \%$ das células após o terceiro processo de congelamento e descongelamento al- ternado em solução salina $0.25 \mathrm{M}$. Estes resultados diferem dos obtidos por Razin, Argman, 1963 para o Mycoplasma laidlawii. Estes autores não observaram a lise do micoplasma, mesmo após dez ciclos de congelamento e descongelamento em solução salina $0.25 \mathrm{M}$. Este método, apesar de não proporcionar uma percentagem de lise elevada, apresenta a vantagem de não utilizar substâncias que possam alterar as proteínas da membrana.

\section{Agradecimentos}

À Coordenação de Aperfeiçoamento de Pessoal de Nível Superior (CAPES) e ao Conselho Nacional de Desenvolvimento Científico e Tecnológico (CNPq) pelas Bolsas de Mestrado e de Iniciação Científica, respectivamente, concedidas às alunas envolvidas.

\section{Referências bibliográficas}

ARCHER, D. B., RODWEL, A. Membrane Proteins of Mycoplasma gallisepticum, Journal of Bacteriology, v. 151, p. 1598-1601, 1982.

CASSEL, G.H., BROWN, B. M.B. Enzyme-linked Immunosorbent assay (ELISA) for detection of anti-mycoplasmal antibody. In: RAZIN, S., TULLY, J.G. (ed.) Methods in Mycoplasmology. Mycoplasma, Characterization. Academic Press, v. 1, 1983. p. 457-469.

DAVISON, M.K., DAVIS, J.K., GAMBILL, G.P., CASSEL, G.H., LINDSEY, J.R. Mycoplasmas of laboratory rodents. In: WHITFORD, H.W. ROSENBUSCH, R.F., LAUERMAN, L.H. (ed.) Mycoplasmosis in Animals: Laboratory diagnosis, lowa State University Press, Ames, lowa. 1994. p. 110.

FREUDT, E.A. Culture media for classic mycoplasmas. In: J. S. RAZIN, J.G. TULLY (ed.). Methods in Mycoplasmology: Mycoplasma characterization. Academic Press. 1983. p. 130.

GRIMELLEC, C.L., ZOLLINGER, M., GIOCONDI, M. C. Analysis Membrane Fractions from Mycoplasma gallisepticum. Biochemical et Biophysical Acta, v. 682, p. 309-318, 1982.

LEVISOHN, S., DAVIDSON, I., VERGADA, M.R.C. Use of ELISA for differential diagnosis of Mycoplasma agalactiaeand $M$. mycoides subspecies mycoides ( $L C)$ in naturally infected goat herds. Research in Veterinary Science, v. 51, p. 66-71, 1991.

NICOLET, J.P.,PAROZ, P.H., KRISTENSEN, B. Grow Medium Constituents Contaminating Mycoplasma Preparations and theirRole in the Study of Membrane Glycoproteins in Porcine Mycoplasmas. Journal of General Microbiology, v. 119, p. 17-26, 1980.
RAZIN, B.S., ARGAMAN, M. Lysis of Mycoplasma, Bacterial Protoplasts, Spheroplasts and L-forms by Various Agents. Journal General Microbiology, v. 30, p. 155-172, 1963.

RAZIN, B.S. Factores Influencing Osmotic fragility of Mycoplasma, Journal General Microbiology, v. 36, p. 451-459, 1964.

. Isolation and characterization of mycoplasma membranes. In: M.F., BARILE, RAZIN, S. (ed.). The Mycoplasmas, Academic Press, v. 1, p. 213-227, 1979.

Cell lysis and isolation of membranes.: In: RAZIN, S., TULLY, J.G. (ed.) Methods in Mycoplasmology: Mycoplasma Characterization, Academic Press, v. 2, p. 225-233, 1983.

ROTTEW, S. Harvest and washing of mycoplasma. In: RAZIN, S., TULLY, J.G. (ed.). Methods in Mycoplasmology. Academic Press, p. 221, 1983.

RAZIN, S. Isolation of mycoplasma membranes by digitonin. J. Bacteriol., v. 110, p. 699-705, 1972.

SHELDRAKE, R.F., ROMALIS, L.F. Evaluation of enzyme-linked immunosorbent assay for the detection of Mycoplasma hyopneumoniae antibody in porcine serum. Australian Veterinary Journal, v. 69, p. 255-258, 1992.

TALKINGTON, F.D., KLEVEN, S.H., BROWN, J. Enzyme-Linked Immunosorbent Assay for the Detection of Antibodies to Mycoplasma gallisepticum in Experimentally Infected Chickens . Avian Diseases. v. 29, p. 53-59, 1984.

VILLEGAS, A.G., KLEVEN, S.H., ANDERSON, D.P. Avian Mycoplasma Membranes as Antigens. Avian Diseases, v. 20, p. 342-354, 1975. 